\author{
Купріна Н.М. \\ доктор економічних наук, профресор \\ кафедра обліку та аудиту \\ Одеська національна академія харчових технологій \\ вул. Канатна 112, м. Одеса, Україна, 65039 \\ E-mail: k.natali@ukr.net \\ ORCID ID: 0000-0003-4645-545X
}

\title{
МЕХАНІЗМИ РЕГУЛЮВАННЯ ПІДПРИЄМНИЦЬКОЇ ДІЯЛЬНОСТІ СУБ'ЄКТІВ НАЦІОНАЛЬНОЇ ЕКОНОМІКИ НАОСНОВІ ТРАНСФОРМАЦІЙНИХ ЗМІН В СУЧАСНИХ РИНКОВИХ УМОВАХ
}

Стаття присвячена дослідженню напрямів регулювання підприємницької діяльності такого важливого суб'єкту національної економіки, як харчова промисловість, через застосування механізму стратегічної реструктуризації, яка враховує фрактори впливу всього спектру глобалізаційних процесів та агресивних змін зовнішнього середовища на національну економіку. Обґрунтовано, що для забезпечення конкурентоспроможності та ефективності ффункціонування суб'єктів національної економіки України, необхідним є механізм застосування стратегічної реструктуризації на підставі дії принципу імпаритету. Розроблено концепцію імпаритетної реструктуризації суб'єктів харчової промисловості України на базі системи принципів, головним з яких є принцип імпаритету (нерівність, захист від негативного впливу дії всього спектру екзогенних і ендогенних факторів), відповідно до макроцілей, які забезпечують вирішення загальнодержавних завдань економічного розвитку країни (економічна і продовольча безпека, конкурентоспроможність національної економіки).

Ключові слова: механізм, підприємницька діяльність, суб'єкти національної економіки, харчова промисловість, транформаційні зміни, імпаритетна реструктуризація, ринкові умови, фактори зовнішнього середовища, забезпечення конкурентоспроможності.

This work is licensed under a Creative Commons Attribution 4.0 International License http://creativecommons.org/licenses/by/4.0/

Постановка проблеми та їі зв'язок з важливими науковими та практичними завданнями. Глобалізаційні процеси, що впливають на розвиток економік різних країн, в тому числі і економіки України, вимагають в сучасних умовах розвитку та функціонування суб'єктів підприємницької діяльності пошуку методів захисту вітчизняних товаровиробників, що сприяє не тільки забезпеченню їх конкурентоспроможності та ефективності діяльності, але й національної економіки. В умовах прояви впливу глобалізаційних процесів і факторів агресивного зовнішнього середовища, належну конкурентоспроможність набуває країна, що має ефективно функціонуючі, конкурентоспроможні суб'єкти підприємницької діяльності, які розвиваються в інтенсивно мінливому зовнішньому середовищі і будують свою діяльність відповідно до стратегій свого розвитку.

Тому дослідження механізмів регулювання підприємницької діяльності суб'єктів національної економіки в ринкових умовах на різних рівнях розміщення іiї об'єктів для забезпечення конкурентоспроможності та ефективності їх діяльності є актуальним напрямом дослідження та вимагає пошуку нових підходів і напрямів ії̈ вирішення. Харчова промисловість, яка функціонує в будь-яких умовах розвитку суспільства та економіки для забезпечення життєдіяльності населення, є дуже важливим суб'єктом національної економіки, що забезпечує іiі економічну та продовольчу безпеку, активно працює й в умовах фінансово-економічних та глобальних криз, та потребує пошуку напрямів іiі розвитку та захисту вітчизняного товаровиробника харчових продуктів від впливу факторів зовнішнього середовища та іноземних конкурентів, що підтверджує актуальність даного дослідження.

Аналіз останніх досліджень і публікацій. Наше дослідження показало, що проблеми регулювання підприємницької діяльності суб'єктів національної економіки, в тому числі й харчової промисловості, на підставі застосування різних механізмів та бізнес-стратегій для забезпечення ефективності їх функціонування, конкурентоспроможності та розвитку були розглянути в наукових працях таких вчених, як М. Аістової, Х. Баранюк, Б. Буркинського, А. Бутенко, О. Гончаренко, С. Дідух, В. Дубницького, О. Іншакова, Г. Клейнера, Г. Карпінської, А. Ковальова, О. Коваленко, Л. Курбацька, І. Ларіонова, Є. Лазарєвої, В. Ляшенко, В.Осипов, П. Осипов, К. Павлова, С. Попова, С. Соколенко,Г. Степанової, А. Татаркіна, С. Халатур та ін., але є дискусійними та потребують 
дослідження на підставі зміни факторів зовнішнього середовища та їх впливу на функціонування суб'єктів національної економіки.

Наше дослідження показало [1, с. 97-112], що існує великий спектр термінів, які характеризують ринкові перетворення суб'єктів підприємницької діяльності на мікроекономічному рівні, основними 3 яких є: реформування, реорганізація, реструктуризація, трансформація, адаптація, реінжиніринг, санація. Так, найбільш широким поняттям $є$ «реформування підприємств», яке, на думку М.Д. Аістової, охоплює і такі перетворювання підприємств, як реструктуризація (зміна стратегії, зміна структури власності й активів, перетворення організаційно-правової форми) i реінжиніринг (оптимізація бізнес-процесів і функцій менеджменту) [2, с. 32-33]. Реформування, не тільки даними вченим, а й іншими [3-5] уявляється як сукупність перетворень у наступних сферах: виробничій, організаційній, кадровій, фінансовій тощо, а реструктуризація, є тим механізмом трансформаційних перетворень суб'єктів підприємницької діяльності, який має комплекс необхідних складових та інструментів для отримання результатів відповідно до поставленої мети управління.

Так, А.І. Ковальов вважає, що реформування i трансформація $є$ «розпливчастими поняттями, які не мають еквівалентного наповнення як перетворення підприємств». На думку вченого, саме реінжиніринг, адаптація, реорганізація, і санація чітко вписуються в класичне поняття змісту такої економічної категорії як «реструктуризація підприємства» [3]. Б.В. Буркинський підкреслює, що специфікою реструктуризації, як стратегії подолання кризового стану суб'єкту господарювання, є як різке підвищення ефективності управління підприємством (організаційні механізми), так і створення механізмів адаптації до конкурентного ринкового середовища (організаційні та економічні механізми). А метою трансформації господарюючих суб'єктів, наприклад, підприємств, є саме процес реструктуризації, що сприяє ефективності їх функціонування та конкурентоздатності продукції, а зміна зовнішнього ринкового середовища функціонування суб'єкта національної економіки має бути саме стимулюванням внутрішніх перетворень на ньому [6, с. 101-114]

Таким чином, як показало наше дослідження [1, с. 97-112], реструктуризація суб'єктів господарювання є одним із найбільш ємних і актуальних ринкових перетворень підприємств, що підтверджує і практика їх діяльності в зарубіжних країнах із розвиненою ринковою економікою, де реструктуризація використовується 3 початку тридцятих років $\mathrm{XX}$ століття і $\epsilon$ перманентним процесом, що виникає в їх діяльності при зниженні показників іiі ефективності, зміні факторів зовнішнього середовища і подальшого технічного, технологічного та іншого інноваційного розвитку, що сприяє формуванню основних моделей ऑiі проведення.

А найбільш ефективним механізмом трансформаційних перетворень в сучасних умовах $є$ саме стратегічна реструктуризація суб'єктів підприємницької діяльності економіки України. Тому що до стратегічних видів реструктуризації об'єктів відносяться ті, проведення яких призводить до змін у стратегічних цілях розвитку і діяльності даного об'єкту дослідження, тому що наші попередні дослідження підтверджують необхідність дослідження саме аспектів проведення стратегічної реструктуризації внаслідок впливу факторів агресивного зовнішнього середовища на суб'єкти національної економіки та необхідність їх захисту й забезпечення конкурентоспроможності та ефективності функціонування, наприклад, такого суб'єкта національної економіки, як харчова промисловість, що потребує подальших досліджень [1, с. 100-111, 122].

Формулювання цілей дослідження. Метою даної статті $€$ формування трансформації діяльності суб'єктів харчової промисловості України, як важливого суб'єкту національної економіки, для забезпечення ii конкурентоспроможності та ефективності функціонування через механізм застосування стратегічної реструктуризації на підставі дії принципу імпаритету та розробці їі концепції.

Виклад основних результатів та їх обгрунтування. Наше дослідження показало [1, с.109-112], що світова економічна криза наприкінці другого десятиріччя XXI століття також суттєво вплинула на стан економік країн світу, згортання бізнесу та банкрутство підприємств та їх об'єднань, збільшення безробіття тощо, що не минуло й економіку України та ії суб'єктів господарювання, а результати проведеного дослідження, підтверджують необхідність проведення стратегічної реструктуризації харчової промисловості та іiї суб'єктів не тільки для підвищення конкурентоспроможності їх діяльності, а, скоріше для іiі збереження на внутрішньому ринку і для захисту вітчизняного виробника в Україні від експансії іноземних товаровиробників. Застосування комплексу заходів реструктуризації дозволить адаптувати національну харчову промисловість та промислові підприємства до нових умов зовнішнього і внутрішнього середовища, які відбуваються під впливом глобалізаційних процесів у економіці України. Такий підхід вимагає виділення нового структурного компоненту реструктуризації як трансформація діяльності (рис. 1).

Як показало наше дослідження [1, с. 123124], стратегічну реструктуризацію вважають активною, тому що комплекс заходів їі проведення носить довгостроковий характер і суттєво впливає на стратегію розвитку, сприяє підвищенню ефективності функціонування і стійкості суб'єкта промисловості в умовах зміни зовнішнього середовища. Оперативна реструктуризація, в свою чергу, є адаптивною до змін зовнішнього середовища без прийняття активних дій суб'єктами промисловості і характеризується стратегією вичікування або «м'яких» коригувань діяльності, 3 чим не можна не погодитись. Тому, на нашу думку, стратегічна і оперативна реструктуризації - це саме форми її проведення, такої ж думки дотримуються й інші вчені [3,7-9]. 


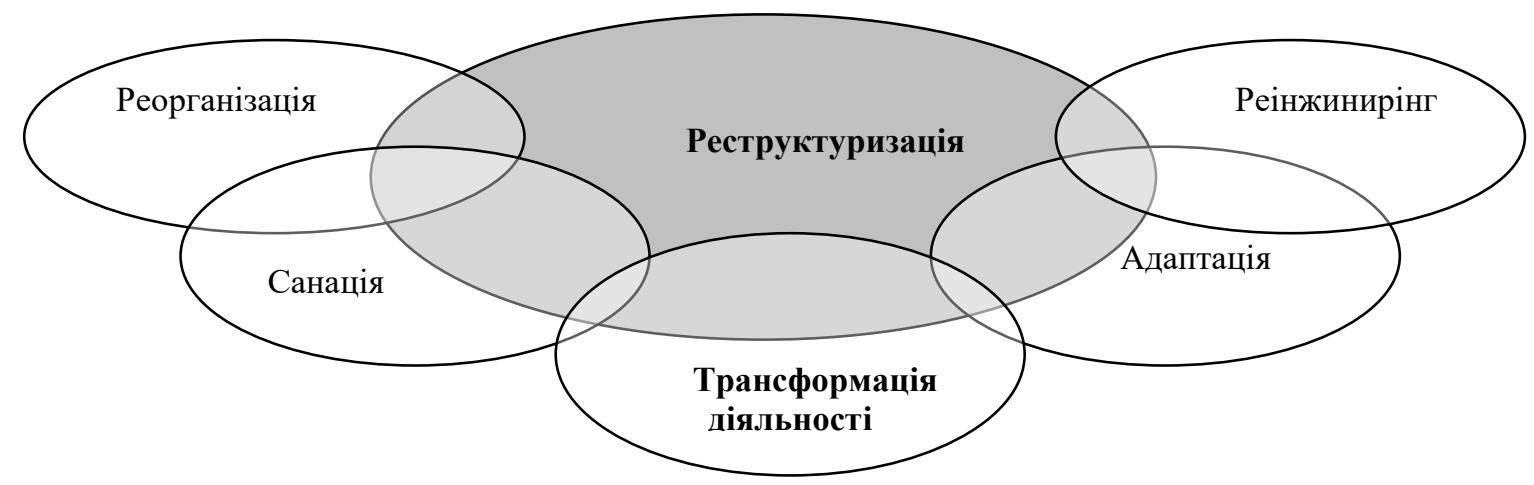

\author{
Рис 1. Склад і структура компонентів стратегічної реструктуризації суб'сктів \\ підприємницької діяльності в сучасних умовах \\ *складено автором [1, с. 111]
}

Проведене нами дослідження [1, с. 178-190; 10, с. 322-325] дозволило вперше виділити актуальний вид стратегічної реструктуризації, як харчової промисловості та iï суб'єктів, так і інших галузей промисловості, - імпаритетної, яка базується на застосуванні принципу імпаритету (виокремлено нами вперше для проведення процесу стратегічної реструктуризації, як прояв обережності об'єкту дослідження конкурентоспроможності від негативного та агресивного впливу факторів зовнішнього середовища. Вперше нами обгрунтовано та розроблено концепцію імпаритетної реструктуризації суб'єктів харчової промисловості України на базі системи принципів, головним 3 яких $є$ принцип імпаритету (нерівність, захист від негативного впливу дії всього спектру екзогенних і ендогенних факторів), відповідно до макроцілей, які забезпечують вирішення загальнодержавних завдань економічного розвитку країни (економічна і продовольча безпека, конкурентоспроможність національної економіки) [1, с. 178-190].

Наше дослідження підтвердило [2, с. 183-184; 10 , с. 325], що даний вид реструктуризації харчової промисловості являє собою трансформацію суб 'єктів харчової промисловості (на мезо-, мікро-, міні- та нанорівнях дослідження) на основі застосування системи механізмів (економічних та організаційних), що дозволяють забезпечувати і підвищувати ефективність діяльності і конкурентоспроможність суб'єктів національної економіки, відповідно до змін зовнішнього середовища і виробленої стратегії їх розвитку. Так, імпаритетна реструктуризація харчової промисловості, на нашу думку, у сформованих умовах господарювання іiі суб'єктів, як суб'єктів підприємницької діяльності України, спрямована на жорстку, помірну та м'яку їх трансформацію: формування інтегрованих формувань вертикального типу, які в сучасних умовах мають більш високу стійкість до «виживання» на внутрішньому ринку і забезпечення конкурентоспроможності, а також і можливості ефективності їх діяльності і подальшого розвитку, перспективи виходу і здатності до активної конкуренції на міжнарод- них ринках (холдинги - жорстка трансформація діяльності, кластерні формування та асоціації - помірна трансформація діяльності, здійснення діяльності підприємств на основі інших підходів та видів аутсорсингу - м'яка трансформація діяльності). Жорстка трансформація суб'єктів харчової промисловості сприяє формуванню в країні власних українських транснаціональних структур, розробка стратегії створення яких може базуватися на використанні зарубіжного досвіду розвитку та формування транснаціональних структур Китаю, Російської Федерації, Індії, Індонезії, Мексики, Венесуели та інших країн. Цей досвід доводить, що національний капітал може чинити опір ТНК і гідно конкурувати тільки у разі його структуризації в сильні промислові, фінансово-промислові та інші утворення, що підтвердили наші попередні дослідження (рис. 2).

У контексті проведеного нашого дослідження, імпаритетна реструктуризація харчової промисловості та їі суб 'єктів, за формою проведення, є стратегічною, за ступенем здійснення (за радикальністю іiі проведення) - кардинальною, за економічним станом об'єкта відповідно до фаз життєвого циклу його розвитку - являє собою трансформацію діяльності галузі та іiі суб 'єктів, за фазою впливу - може бути як превентивною, так і наступною, а також носить соціально орієнтований характер за соціально орієнтованими напрямами іï проведення [1, с. 130, 184].

Для характеристики сутності імпаритетної реструктуризації харчової промисловості нами обгрунтуванні та розроблені принципи, фактори як іiі рушійні сили, цілі, суб'єкти, об'єкти, механізми, а також інструменти iї проведення [1, с. 184-191]. Так, функції проведення імпаритетної реструктуризації охоплюють всі рівні діяльності суб'єктів харчової промисловості - підприємств, їх об'єднань та формувань, i їх результати: забезпечення і підвищення ефективності діяльності та конкурентоспроможності, соціально орієнтовану спрямованість їх діяльності; захист від поглинання, розвиток діяльності, забезпечення конкурентоспроможності національної економіки. 


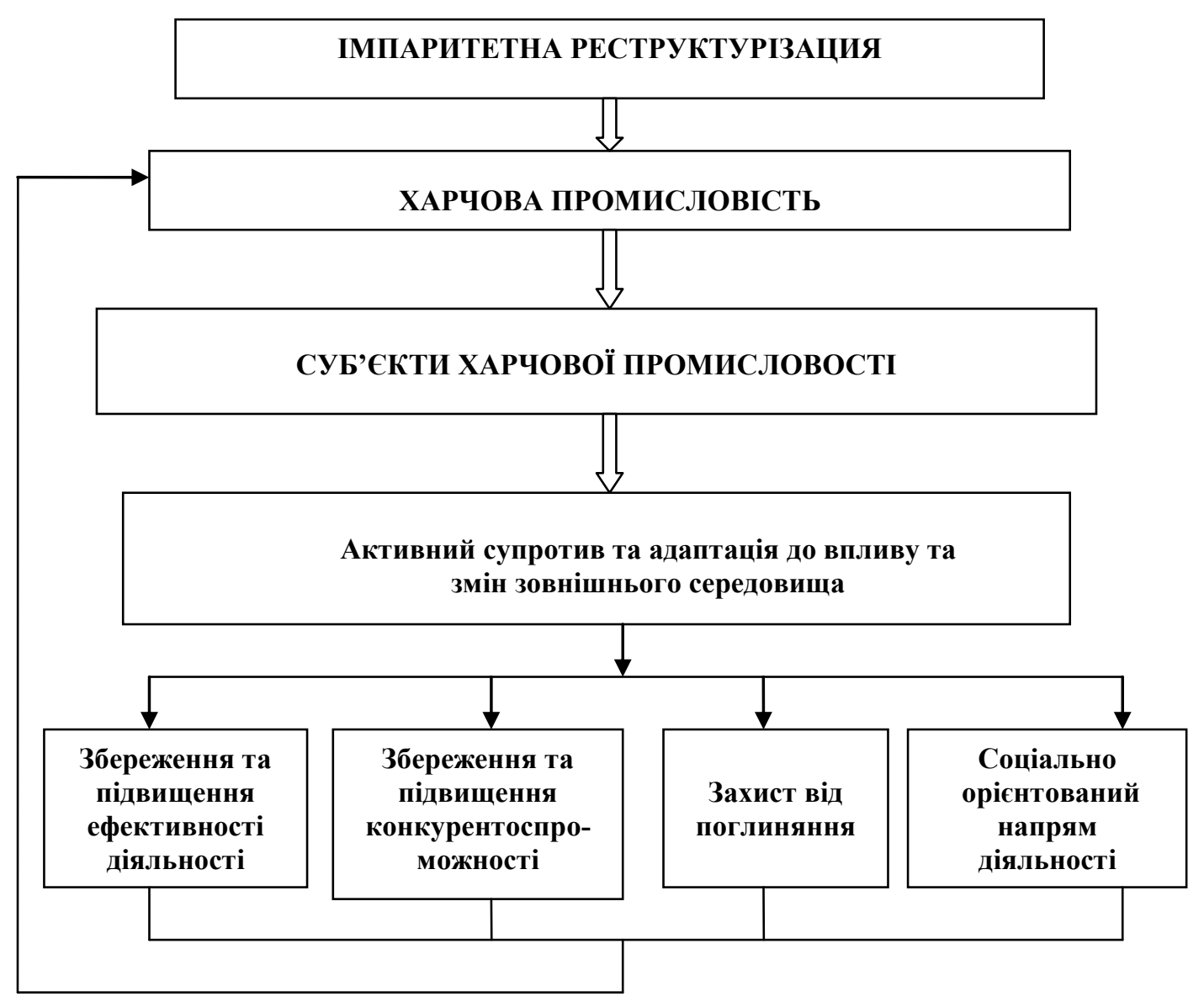

Рис. 2 - Сутність імпаритетної реструктуризації харчової промисловості в сучасних умовах* *авторська розорбка [1, с. 187]

Як показали наші дослідження [1, с. 186-189], в контексті проведеного дослідження, принципи, на нашу думку, - це базові положення проведення імпаритетної реструктуризації у відповідності з цілями їі проведення, стратегією розвитку суб'єктів національної економіки, наприклад, харчової промисловості, а також факторами впливу зовнішнього середовища (рис. 3).

Факторами проведення імпаритетної реструктуризації харчової промисловості, як іiі рушійними силами, на нашу думку, є зміни зовнішнього середовища навколо суб'єктів харчової промисловості, зокрема промислових підприємств та їх об'єднань: інтернаціоналізація, інтеграція, концентрація капіталу, конкуренція, підприємництво, інноваційний розвиток, поглинання, кризові явища тощо [1, с. 185, 189-190].

Для розробки методики проведення імпаритетної реструктуризації харчової промисловості необхідно визначити коло суб'єктів і об'єктів та напрямки іiі проведення. Наше дослідження показало [1, с. 189], що:

- суб'єктами даного виду реструктуризації харчової промисловості є: промислові підприємства та їх об'єднання і формування; органи державного управління; інфраструктурні підприємства і організа- ції, що забезпечують функціонування харчової промисловості та пї суб'єктів; венчурні підприємства і організації, що забезпечують інноваційний розвиток діяльності; торговельні підприємства і постачальники ТМЦ, що забезпечують процес постачання і реалізації продукції (робіт, послуг), транспортні підприємства та організації тощо;

- всю сукупність об'єктів імпаритетної реструктуризації можна об'єднати в такі групи: харчова промисловість, суб'єкти харчової промисловості: підприємства, їх об'єднання та формування, діяльність суб'єктів харчової промисловості та її види, процеси, структурні підрозділи, технології; персонал, продукція (роботи, послуги) тощо;

- інструментами проведення імпаритетної реструктуризації, що складаються з іiї організаційних та економічних механізмів, $є$ аудит спеціального призначення (внутрішній і зовнішній), аналіз (стратегічний, фінансовий, управлінський), стратегічний управлінський облік, які, на нашу думку, є оптимальним інструментом іії проведення, тому що охоплюють такі функції управління, як планування, аналіз, облік i контроль, але й моніторинг для спостереження результативності проведення імпаритетної реструктуризації. 


\section{ІМПАРИТЕНА РЕСТРУКТУРИЗАЦІЯ}

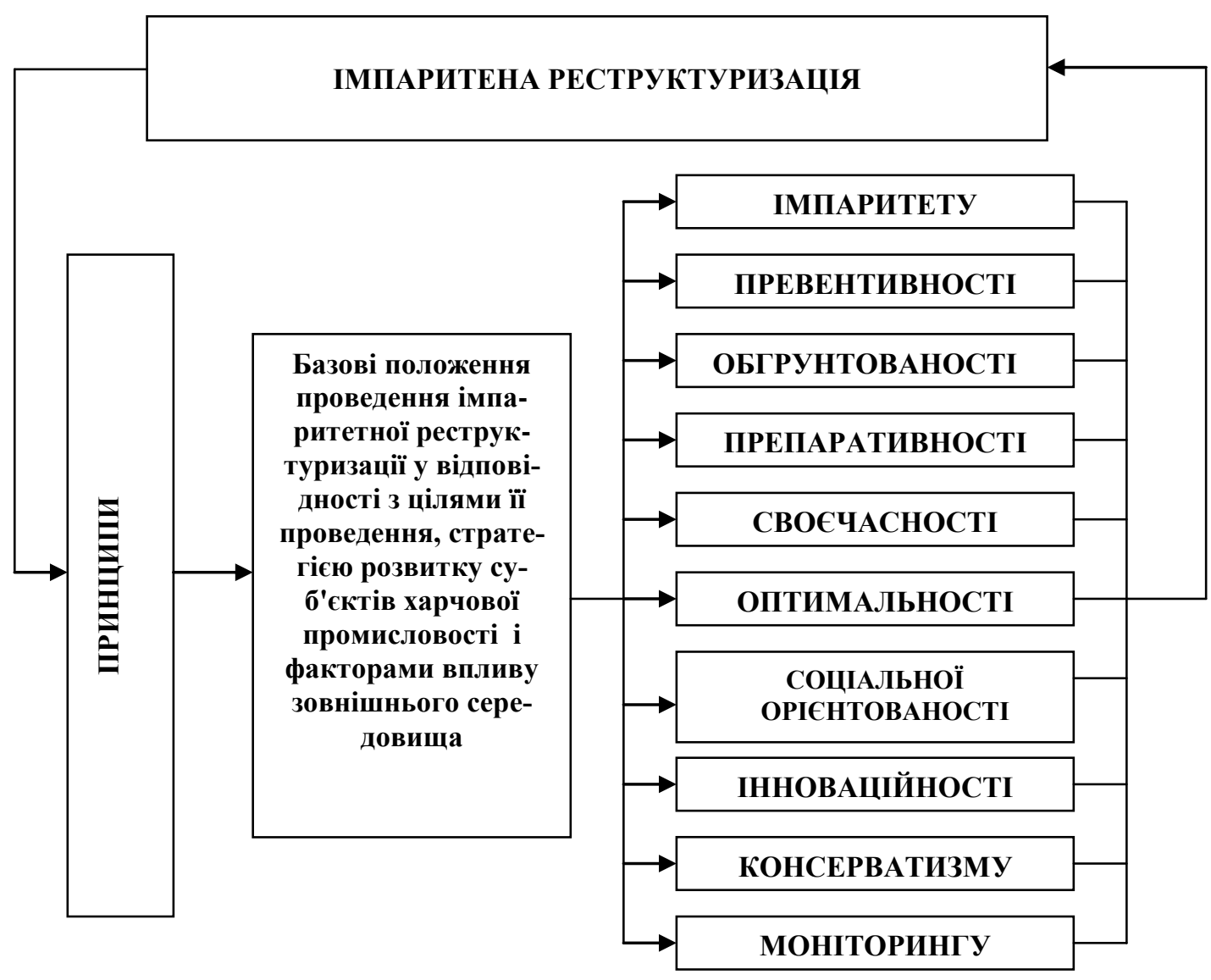

Рис. 3. Основні принципи імпаритетної реструктуризації харчової промисловості та її суб'сктів *

*авторська розорбка [1, с. 187]

Висновки та перспективи подальших досліджень. Проведене дослідження підтвердило, що реструктуризація суб'єктів господарювання є одним i найбільш ємних і актуальних ринкових трансформаційних перетворень суб'єктів підприємницької діяльності, що підтверджує і практика їх діяльності в зарубіжних країнах з розвиненою ринковою економікою, де реструктуризація використовується з початку тридцятих років XX століття і $є$ перманентним процесом, що виникає в їх діяльності при зниженні показників їі ефективності, зміні факторів зовнішнього середовища i подальшого технічного, технологічного та іншого інноваційного розвитку, що сприяє формуванню основних моделей їі проведення.

Досліджуючи структурні компоненти процесу стратегічної реструктуризації, які виокремлюються вченими, виявлено, що між реінжинірингом і адаптацією, як досить «м'якими» коригуваннями поточної діяльності суб'єкта господарювання, викликаними впливом зовнішнього середовища, і санацією та реорганізацією діяльності суб'єкта господарювання, відсутній ще один іiї структурний компонент, що характеризує реакцію підприємства на різку зміну умов зовнішнього середовища і значно впливає на ефектив- ність діяльності і конкурентоспроможність, але який не несе таких радикальних заходів, як реорганізація діяльності і не завжди потребує іiі санації, такий як трансформація діяльності.

Обгрунтована об'єктивна необхідність проведення реструктуризації харчової промисловості і виділити такий актуальний іiі вид як імпаритетну, що дозволяє зберегти ефективність функціонування i соціальні аспекти діяльності, а також конкурентоспроможність національної економіки та іiі суб'єктів в умовах жорсткої конкуренції на внутрішньому ринку України.

Вперше розроблено концепцію імпаритетної реструктуризації суб'єктів харчової промисловості України на базі системи принципів, головним з яких $є$ принцип імпаритету (нерівність, захист від негативного впливу дії всього спектру екзогенних і ендогенних факторів), відповідно до макроцілей, які забезпечують вирішення загальнодержавних завдань економічного розвитку країни (економічна і продовольча безпека, конкурентоспроможність національної економіки), виділено фактори впливу, суб'єкти та об'єкти їі проведення. 


\title{
Література
}

1. Купріна Н.М. Забезпечення конкурентоспроможності харчової промисловості України: теорія і практика: монографія. Одеса: Видавничий дім «Гельветика», Одеса. 2019. 304 с.

2. Аистова М.Д. Реструктуризация предприятий: вопросы управления. Стратегии, координация структурных параметров, снижение сопротивления преобразованиям. М.: Альпина Паблишер, 2002. 287 с.

3. Ковалев А.И. Управление реструктуризацией предприятия: монография. К.: АВРИО, 2006. 367 с.

4. Козицька Г.В. Реструктуризація підприємств як фактор перебудови економіки України // Галицький економічний вісник. 2006. Вип. 3(10). С. 111-118.

5. Гавриш О.А., Іванова Т.В. Механізм реструктуризації промислових підприємств // Економічний вісник НТУУ «КПІ». 2011. URL: http:// economy.kpi.ua/files/ files/ 33_kpi_2011 (дата звернення: 20.10.2021).

6. Буркинський Б.В. Трансформація моделей розвитку підприємств. Одеса: ІПРЕЕД, 2001. 335 с.

7. Минакова С.М. Реструктуризация как эффективное средство повышения конкурентоспособности. // Методы и способы управления развитием транспортных систем: зб. наук.праць. Одеса: ОНМУ, 2002. Вип. 3.С. $156-161$

8. Оганезов А.В. Концепція реструктуризації переробних підприємств АПК // Зб. наук. праць Черкаського державного технологічного університету. Сер.Економічні науки. Черкаси: ЧДТУ, 2004. №15. С. $136-137$.

9. Лавриненко В.В. Реструктуризація промислових підприємств і формування їх інвестиційного потенціалу: автореф. дис.... канд. екон. наук: 08.06.01: захист 21.06.2000 р. / Наук.кер. Швиданенко Г.О. К.: Київський національний економічний університет, 2000. 22 c. doi: 1142/S0218654300000041

10. Купріна Н.М. Персистентна трансформація харчової промисловості України в контексті забезпечення іiї конкурентоспроможності // Економічні та соціальні аспекти розвитку України на початку XXI століття: матеріали IX міжнародної науково-практичної конференції, Одеса, 19-20 жовтня 2021 р./ Одеська національна академія харчових технологій, Одеса, 2021. C. $\quad$ 322-327. https://www.onaft.edu.ua/download/konfi/2021/Collection-of-abstracts-ekonom-19-20-21.pdf (дата звернення: 1.11.2021).

\author{
Kuprina N. \\ Doctor of Economics, Professor \\ Department of Accounting and Auditing \\ Odessa National Academy of Food Technologies \\ Kanatna str., 112, Odesa, Ukraine, 65039 \\ E-mail:k.natali@ukr.net \\ ORCID ID: 0000-0003-4645-545X
}

\section{MECHANISMS OF ENTERPRENEURIAL ACTIVITIES REGULATION OF THE NATIONAL ECONOMY SUBJECTS ON THE BASIS OF TRANSFORMATIONAL CHANGES IN MODERN MARKET CONDITIONS}

Globalization processes affecting the development of economies of different countries, including the economy of Ukraine, require in modern market conditions and the functioning of business entities to find methods of protection of domestic producers, which contributes not only to their competitiveness and efficiency, but also national economy. This article is devoted to the study of business regulation of such an important subject of the national economy as the food industry, through the use of strategic restructuring, which takes into account the impact of the whole spectrum of globalization and aggressive changes in the national economy.

The study confirmed that the restructuring of economic entities is one of the most capacious and relevant market transformational conversions of business entities, which confirms the practice of their activities in foreign countries with developed market economies, where restructuring is a permanent process that occurs in their activity at decrease in indicators of its efficiency, change of factors of external environment and the further technical, technological and other innovative development that promotes formation of the basic models of its carrying out. Examining the structural components of the strategic restructuring process identified by scientists, it was found that between reengineering and adaptation, as fairly "soft" adjustments to the current activities of the entity caused by environmental influences, and rehabilitation and reorganization of the entity,there is another missing structural component that characterizes the company's response to ab- 
rupt changes in environmental conditions and that significantly affects the efficiency and competitiveness, but which does not carry such radical measures as reorganization and does not always require its rehabilitation, such as transformation. It has been substantiated that in order to ensure competitiveness and efficiency of functioning of the subjects of the national economy of Ukraine, a mechanism of application of strategic restructuring on the basis of the principle of imperative is necessary. For the first time the concept of impartial restructuring of the food industry of Ukraine was developed on the basis of a system of principles, the main of which is the principle of impartiality (inequality, protection from the negative impact of the whole spectrum of exogenous and endogenous factors),according to macrogoals which ensure solving national problems of economic development of the country (economic and food security, competitiveness of the national economy).

Key words: mechanism, entrepreneurial activity, subjects of national economy, food industry, transformational changes, imperative restructuring, market conditions, environmental factors, ensuring competitiveness.

\section{References}

1. Kuprina, N. M. (2019). Zabezpechennia konkurentospromozhnosti kharchovoi promyslovosti Ukrainy: teoriia i praktyka. Vydavnychyi dim «Helvetyka».

2. Aistova, M. D. (2002). Restrukturizatsiya predpriyatiy: voprosyi upravleniya. Strategii, koordinatsiya strukturnyih parametrov, snizhenie soprotivleniya preobrazovaniyam. Alpina Pablisher.

3. Kovalev, A. I. (2006). Upravlenie restrukturizatsiey predpriyatiya. AVRIO.

4. Kozytska, H. V. (2006). Restrukturyzatsiia pidpryiemstv yak faktor perebudovy ekonomiky Ukrainy. Halytskyi ekonomichnyi visnyk, 3(10), 111-118.

5. Havrysh, O. A., \& Ivanova, T. V. (2011). Mekhanizm restrukturyzatsii promyslovykh pidpryiemstv. Ekonomichnyi visnyk NTUU «KPI». Retrieved October 20, 2021, from http:// economy.kpi.ua/files/ files/ 33_kpi_2011

6. Burkynskyi, B.V. (2001). Transformatsiia modelei rozvytku pidpryiemstv. IPREED.

7. Minakova, S. M. (2002). Restrukturizatsiya kak effektivnoe sredstvo povyisheniya konkurentosposobnosti. Metodyi i sposobyi upravleniya razvitiem transportnyih system, (3), 156-161.

8. Ohanezov, A. V. (2004). Kontseptsiia restrukturyzatsii pererobnykh pidpryiemstv APK. Zb. nauk. prats Cherkaskoho derzhavnoho tekhnolohichnoho universytetu, (15), 136-137.

9. Lavrynenko, V. V. (2000). Restrukturyzatsiia promyslovykh pidpryiemstv i formuvannia yikh investytsiinoho potentsialu (avtoref. dys.... kand. ekon. nauk: 08.06.01: zakhyst 21.06.2000 r. / Nauk.ker. Shvydanenko, H. O.). Kyiv: Kyivskyi natsionalnyi ekonomichnyi universytet, 1-22. doi: 1142/S0218654300000041

10. Kuprina, N. M. (2021). Persystentna transformatsiia kharchovoi promyslovosti Ukrainy v konteksti zabezpechennia yii konkurentospromozhnosti. In Ekonomichni ta sotsialni aspekty rozvytku Ukrainy na pochatku XXI stolittia: materialy 2021 mizhnarodnoi naukovo-praktychnoi konferentsii (pp. 322-327). Odesa; Odeska natsionalna akademiia kharchovykh tekhnolohii. Retrieved November 01, 2021, from https://www.onaft.edu.ua/download/konfi/2021/Collection-of-abstracts-ekonom-19-20-21.pdf

Received 8 November 2021

Approved 22 November 2021 Available in Internet 30.12.2021

Цитування згідно ДСТУ 8302:2015

Купріна Н.М. Механізми регулювання підприємницької діяльності суб'єктів національної економіки на основі трансформаційних змін в сучасних ринкових умовах // Економіка харчової промисловості. 2021. Т. 13, вип. 4. C. 27-33. doi 10.15673/fie.v13i4.2216

Cite as APA style citation

Kuprina, N. (2021). Mechanisms of enterpreneurial activities regulation of the national economy subjects on the basis of transformational changes in modern market conditions. Food Industry Economics, 13(4), 27-33. doi 10.15673/fie.v13i4.2216 